\title{
Dok. 2. \\ Konkluzji prezydencji z posiedzenia Rady Europejskiej w Brukseli (21-22 czerwca 2007 r.)
}

Europa jest zjednoczona w swoim przekonaniu, że tylko pracując razem jesteśmy w stanie reprezentować swoje interesy i cele w przyszłości. Unia Europejska jest zdeterminowana, by jej ideały zrównoważonego, skutecznego i sprawiedliwego porządku gospodarczego i społecznego przyczyniały się do globalnego procesu.

Unia Europejska ponosi podwójną odpowiedzialność. Aby zagwarantować sobie w przyszłości rolę aktywnego uczestnika w szybko zmieniającym się świecie i wobec coraz większych wyzwań, musimy utrzymywać i rozwijać zdolność Unii Europejskiej do działania oraz ponoszenia odpowiedzialności przed obywatelami. Dlatego musimy skupić nasze wysiłki na koniecznym procesie reformy wewnętrznej. Jednocześnie zadaniem Unii Europejskiej jest kształtowanie polityki europejskiej tu i teraz z korzyścią dla obywateli Europy.

1. Przykładami ostatnich udanych inicjatyw są: rozporządzenie w sprawie roamingu, które zmniejsza koszt nowoczesnej komunikacji w Europie, utworzenie europejskiego obszaru płatniczego, dzięki czemu łatwiejsze staje się wspólne podróżowanie i życie w UE, oraz ciągła poprawa w dziedzinie praw konsumenta, które gwarantują obywatelom te same wysokie standardy na terenie całej Unii Europejskiej.

2. Podejmując decyzje w sprawie zintegrowanej polityki dotyczącej klimatu i energii, Rada Europejska obradująca wiosną 2007 roku podkreśliła synergie istniejące między tymi dwoma kluczowymi obszarami i wytyczyła drogę ku lepszej ochronie klimatu i odpowiedzialnemu traktowaniu energii.

3. Ściślejsza współpraca policyjna i sądowa na poziomie transgranicznym oznacza większe bezpieczeństwo dla wszystkich. UE działa jednocześnie na rzecz ochrony i wzmocnienia swobód obywatelskich na poziomie europejskim.

4. Udział w codziennym życiu obywateli i zagwarantowanie zdolności Unii Europejskiej do działania w przyszłości: mając na uwadze taki dwojaki cel, Rada Europejska przyjęła dziś poniższe konkluzje.

5. Rada Europejska podkreśla fundamentalne znaczenie wzmocnienia komunikacji z obywatelami Europy, zapewnienia pelnych i kompleksowych informacji na temat Unii Europejskiej oraz angażowania ich w stałym dialogu. Będzie to miało szczególne znaczenie podczas zbliżającej się konferencji międzyrządowej i procesu ratyfikacji.

\section{REFORMA TRAKTATÓW}

1. Rada Europejska stoi na stanowisku, że po dwóch latach niepewności związanej z reformą Traktatu Unii, nadeszła pora, aby kwestia ta znalazła rozstrzygnięcie i aby Unia osiagnęła postępy w tym zakresie. Okres refleksji dał sposobność do przeprowadzenia szerokiej debaty publicznej oraz umożliwił przygotowanie warunków sprzyjających wypracowaniu rozwiązania. 
2. W tych okolicznościach Rada Europejska z zadowoleniem przyjmuje sporządzone przez prezydencję sprawozdanie (10659/07) na mocy mandatu przyznanego jej w czerwcu 2006 roku i jest zdania, że szybkie rozwiązanie tej kwestii ma znaczenie priorytetowe.

3. W tym celu Rada Europejska postanawia zwołać konferencję międzyrządową i wzywa prezydencję do bezzwłocznego podjęcia niezbędnych kroków zgodnie z art. 48 TUE z myślą o rozpoczęciu tej konferencji przed końcem lipca natychmiast po spełnieniu stosownych wymogów prawnych.

4. Prace konferencji międzyrządowej będą prowadzone zgodnie z mandatem określonym w załączniku I do niniejszych konkluzji. Rada Europejska wzywa kolejną prezydencję do przygotowania projektu tekstu Traktatu zgodnie z zapisami mandatu oraz do przedłożenia tego projektu konferencji międzyrządowej niezwłocznie po jej rozpoczęciu. Konferencja międzyrządowa zakończy swoje prace możliwie najszybciej, a w każdym przypadku przed końcem 2007 roku, tak aby uzgodniony tekst Traktatu mógł być ratyfikowany przed wyborami do Parlamentu Europejskiego w czerwcu 2009 roku.

5. Konferencja międzyrządowa będzie prowadzona pod ogólnym zwierzchnictwem szefów państw lub rządów wspieranych przez członków Rady ds. Ogólnych i Stosunków Zewnętrznych. W konferencji będzie uczestniczył przedstawiciel Komisji. Parlament Europejski będzie ściśle współpracował z konferencją i uczestniczył w jej pracach za pośrednictwem trzech przedstawicieli. Obsługę biurową na potrzeby konferencji zapewni Sekretariat Generalny Rady.

6. Po zasięgnięciu opinii przewodniczącego Parlamentu Europejskiego Rada Europejska zwraca się do Parlamentu Europejskiego o przedstawienie do października 2007 roku - w celu stworzenia korzystnych warunków dla rozwiązania kwestii przyszłego składu Parlamentu Europejskiego w stosownym czasie przed wyborami w 2009 roku - projektu inicjatywy przewidzianej w Protokole 34 uzgodnionym podczas konferencji międzyrządowej w 2004 roku.

7. Wzywa się kolejną prezydencję do dopilnowania, aby kraje kandydujące otrzymywały $\mathrm{w}$ trakcie całej konferencji międzyrządowej pełne i regularne informacje dotyczące jej prac.

\section{WYMIAR SPRAWIEDLIWOŚCI I SPRAWY WEWNĘTRZNE}

1. Dzięki działaniom prowadzonym na podstawie programu z Tampere i programu haskiego osiagnięto znaczne postępy w rozwijaniu Unii jako przestrzeni wolności, bezpieczeństwa i sprawiedliwości. Rada Europejska podkreśla konieczność dalszej realizacji tych programów oraz pracy nad kolejnymi inicjatywami będącymi kontynuacją tych programów w celu dalszego wzmocnienia wewnętrznego bezpieczeństwa Europy oraz podstawowych wolności i praw obywateli.

2. Niedawne wydarzenia ponownie wskazały na potrzebę szybkiego postępu w opracowaniu wszechstronnej europejskiej polityki w dziedzinie migracji opartej na wspólnych zasadach politycznych, uwzględniającej wszystkie aspekty migracji (agendę migracji i rozwoju, jak również aspekty wewnętrzne, takie jak migracja legalna, integracja, ochrona uchodźców, kontrola granic, readmisja oraz zwalczanie nielegalnej migracji i handlu ludźmi), opartej na prawdziwym partnerstwie z państwami trzecimi i w pełni zintegrowanej z zewnętrznymi politykami Unii. Rada Europejska z zadowole- 
niem przyjmuje dotychczasowe postępy w realizacji działań priorytetowych koncentrujących się na Afryce i regionie śródziemnomorskim, w tym ostatnie misje UE w Afryce oraz konkretną współpracę z partnerami afrykańskimi i euro-śródziemnomorskimi, w ramach globalnego podejścia do kwestii migracji i wzywa do przyspieszenia $i$ intensyfikacji tych priorytetowych działań. Rada Europejska z zadowoleniem przyjmuje również komunikat Komisji z 16 maja 2007 r. w sprawie stosowania globalnego podejścia do migracji do regionów wschodnich i południowo-wschodnich sąsiadujących z UE. Przyznając, że istnieje potrzeba zintensyfikowanej i bardziej skoordynowanej współpracy z tymi regionami, Rada Europejska zatwierdza konkluzje Rady z 18 czerwca 2007 r., w tym wykaz środków priorytetowych. Rada Europejska wzywa państwa członkowskie i Komisję do zapewnienia przydziału odpowiednich zasobów ludzkich i finansowych, w istniejących ramach finansowych, w celu umożliwienia terminowej realizacji wszechstronnej polityki migracyjnej.

3. Rada Europejska podkreśla znaczenie bliższej współpracy z państwami trzecimi w zarządzaniu przepływami migracyjnymi. Konkretne partnerstwa z państwami trzecimi w dziedzinie migracji mogłyby przyczynić się do stworzenia spójnej polityki migracyjnej, która łączyłaby środki ułatwiające właściwe zarządzanie możliwościami legalnej migracji i korzyściami z nich płynącymi - przy poszanowaniu kompetencji państw członkowskich i szczególnych potrzeb ich rynków pracy - ze środkami służącymi zwalczaniu nielegalnej migracji, ochronie uchodźców i stawianiu czoła zasadniczym przyczynom migracji, przy jednoczesnym korzystnym oddziaływaniu na rozwój w krajach pochodzenia. Należy dokładniej zbadać ewentualność tworzenia partnerstw na rzecz mobilności, jak również możliwość migracji wahadłowej w świetle komunikatu Komisji z 16 maja 2007 r.; w tym kontekście Rada Europejska zatwierdza konkluzje Rady z 18 czerwca 2007 r. Rada Europejska jest przekonana, że nielegalne zatrudnienie stanowi jeden z głównych czynników zachęcających do nielegalnej imigracji. W związku z tym podkreśla znaczenie wniosku dotyczącego dyrektywy określającej zasady unikania nielegalnego zatrudniania obywateli państw trzecich.

4. Rada Europejska potwierdza potrzebę wzmocnienia zdolności Unii do udziału w zarządzaniu zewnętrznymi granicami państw członkowskich i podkreśla znaczenie dalszego wzmacniania potencjału agencji FRONTEX w tej kwestii. Wspólne operacje na zewnętrznych granicach państw członkowskich przyczyniają się do zwalczania nielegalnej migracji i ratowania istnień ludzkich; należy je zatem kontynuować. Rada Europejska z zadowoleniem przyjmuje w związku z tym porozumienie osiagnięte w sprawie ustanowienia zespołów szybkiej interwencji granicznej, uruchomienia sieci patroli wybrzeża i utworzenia scentralizowanego zestawu narzędzi technicznych, które można udostępnić państwom członkowskim. Rada Europejska wzywa wszystkie zainteresowane strony do dołożenia wszelkich starań służących jak najszybszemu osiągnięciu operacyjności przez zespoły szybkiej interwencji granicznej oraz do pełnego wykorzystania nowych możliwości, jakie stwarza sieć patroli wybrzeża i wspomniany wyżej zestaw narzędzi, w tym do zwiększenia liczby i wzmocnienia wspólnych patroli. Przywołując program haski, Rada Europejska potwierdza, że solidarność europejska i sprawiedliwy podział obowiązków znajdują się pośród podstawowych zasad kierujących działaniami Europy w zakresie zarządzania granicami zewnętrznymi UE, zgodnie z systemem zintegrowanego zarządzania. 
5. Rada Europejska z zadowoleniem przyjmuje niedawne porozumienie dotyczące rozporządzenia $w$ sprawie wizowego systemu informacyjnego (VIS) i wymiany między państwami członkowskimi informacji o wizach krótkoterminowych, oraz decyzję Rady w sprawie dostępu do danych w VIS dla wyznaczonych organów państw członkowskich i Europolu w celu zapobiegania przestępstwom terrorystycznym, ich wykrywania i prowadzenia odnośnych dochodzeń. Wraz z rozwojem nowoczesnych środków kontroli i identyfikacji, stanowią one kolejne istotne kroki na drodze usprawnienia wymiany informacji między państwami członkowskimi, przyczyniając się w ten sposób do poprawy zarządzania wspólną polityką wizową oraz zwiększenia bezpieczeństwa obywateli. Rada Europejska wzywa do szybkiego wdrożenia rozporządzenia w sprawie VIS i powyższej decyzji Rady.

6. Rada Europejska z zadowoleniem przyjmuje także wysiłki podjęte z myślą o polepszeniu ciągłej i pogłębionej współpracy na poziomie UE i pomiędzy państwami członkowskimi w obszarze integracji i dialogu międzykulturowego. Rada Europejska z zadowoleniem przyjmuje w szczególności konkluzje Rady z 12 czerwca w sprawie wzmocnienia polityk integracyjnych w UE przez propagowanie koncepcji jedności w różnorodności. Podkreśla znaczenie kolejnych inicjatyw służących ułatwieniu wymiany doświadczeń państw członkowskich dotyczących polityk integracyjnych.

7. Rada Europejska potwierdza swoje zaangażowanie w urzeczywistnienie - do końca 2010 roku - wspólnego europejskiego systemu azylowego jako części wszechstronnej europejskiej polityki migracyjnej.

8. Rada Europejska dokona przeglądu stanu wdrożenia wszechstronnej polityki migracyjnej na kolejnym posiedzeniu w grudniu 2007 roku na podstawie opracowanego przez Komisję okresowego sprawozdania z postępów. Sprawozdanie to powinno przedstawiać postępy w stosowaniu globalnego podejścia do kwestii migracji wobec Afryki i regionu śródziemnomorskiego, jak również pierwsze postępy w stosowaniu globalnego podejścia do kwestii migracji wobec wschodnich i południowo-wschodnich regionów sąsiadujących z Unią Europejska.

9. Rozszerzenie obszaru Schengen poprawi jakość codziennego życia obywateli, w związku z czym kwestia ta pozostaje ważnym priorytetem dla UE. Rada Europejska z zadowoleniem przyjmuje prace przygotowawcze podjęte $w$ ramach projektu SIS One4All i zachęca państwa członkowskie uczestniczące w projekcie do dalszych działań służących spełnieniu wszystkich wymogów, określonych w konkluzjach Rady (ds. WSiSW) z 5-6 grudnia 2006 r., koniecznych do zniesienia kontroli na wewnętrznych granicach lądowych i morskich do końca grudnia 2007 roku oraz na granicach powietrznych nie później niż do marca 2008 roku, pod warunkiem spełnienia wszystkich tych wymogów. Rada Europejska wzywa jednocześnie Komisję do zakończenia pozostałych prac w zaplanowanym terminie tak, by projekt SIS II został sfinalizowany nie później niż do grudnia 2008 roku.

10. Nadal konieczne jest podejmowanie szczególnych wysiłków na rzecz wzmocnienia współpracy policyjnej i sądowej oraz walki z terroryzmem. Obywatele Europy oczekuja, że UE i jej państwa członkowskie podejmą zdecydowane działania na rzecz ochrony ich wolności i bezpieczeństwa, w szczególności w dziedzinie walki z terroryzmem i przestępczością zorganizowana. 
11. Niedawna decyzja dotycząca włączenia podstawowych postanowień traktatu z Prüm do ram prawnych Unii przyczyni się do zintensyfikowania transgranicznej współpracy policyjnej. W tym samym kontekście Unia Europejska podkreśla znaczenie dalszego wzmacniania zdolności operacyjnych Europolu i z zadowoleniem przyjmuje decyzję Rady o przekształceniu konwencji o Europolu w decyzję Rady, zgodnie z konkluzjami Rady (ds. WSiSW) z 12-13 czerwca 2007 r. Ochrona praw obywateli jest tak samo istotna dla utworzenia przestrzeni wolności, bezpieczeństwa i sprawiedliwości, jak zagwarantowanie ochrony obywatelom Europy. W tym kontekście Rada Europejska szczególnie wzywa Radę, by przed końcem roku osiągnęła porozumienie odnośnie do decyzji ramowej w sprawie ochrony danych osobowych przetwarzanych w ramach współpracy policyjnej i sądowej w sprawach karnych.

12. Rada Europejska wzywa do jak najszybszego kontynuowania prac dotyczących praw procesowych w postępowaniu karnym tak, by przyczynić się do wzrostu zaufania do systemów prawnych innych państw członkowskich, a tym samym ułatwienia wzajemnego uznawania decyzji sądowych. Niedawne ogólne porozumienie na temat decyzji ramowej w sprawie zwalczania niektórych form rasizmu i ksenofobii stanowi wyraźny sygnał zaangażowania Europy w walkę z nietolerancja.

13. W interesie obywateli europejskich konieczne jest szybkie porozumienie odnośnie do rozporządzenia w sprawie prawa właściwego dla zobowiązań umownych (Rzym I), rozporządzenia w sprawie jurysdykcji i prawa właściwego w sprawach małżeńskich (Rzym III) i rozporządzenia w sprawie obowiazzów alimentacyjnych.

14. Wzywa się Radę, by kontynuowała prace nad oceną tego, czy przepisy wspólnotowego prawa w zakresie prawa umów, w tym prawa umów konsumenckich, tworzą konsekwentną i spójną całość.

15. Rada Europejska dostrzega postępy osiagnięte w opracowywaniu prawodawstwa dotyczącego wymiany informacji na poziomie europejskim o wyrokach skazujących w sprawach karnych w poszczególnych krajach i zwraca się do Rady o dopilnowanie, by krajowe systemy rejestrów karnych zostały ze sobą jak najszybciej połączone za pomocą europejskiej sieci. Rada nadal powinna również propagować elektroniczną drogę komunikacji w sprawach prawnych („e-sprawiedliwośé”) zarówno w dziedzinach karnych, jak i cywilnych.

16. Rada Europejska z zadowoleniem przyjmuje komunikat Komisji na temat walki z cyberprzestępczością i wzywa do opracowania ram polityki w tej dziedzinie.

\section{ZAGADNIENIA GOSPODARCZE, SPOLECZNE I ŚRODOWISKOWE}

IV. 1. Dalsze wzmacnianie czterech swobód rynku wewnętrznego (swobodny przepływ towarów, osób, usług i kapitału) oraz usprawnianie jego funkcjonowania nadal ma nadrzędne znaczenie dla wzrostu, konkurencyjności i zatrudnienia. Rada Europejska oczekuje na przedstawienie jesienią przez Komisję przeglądu jednolitego rynku, wraz z towarzyszącymi mu wnioskami. Wzywa Radę i Parlament Europejski do osiagnięcia szybkich postępów w kwestii nowego podejścia oraz rozporządzeń w sprawie wzajemnego uznawania, w stosownych przypadkach, bez uszczerbku dla harmonizacji krajowych przepisów technicznych. 
V. 2. Rada Europejska odnotowuje postępy osiągnięte przez Radę w zakresie projektu dyrektywy w sprawie urzeczywistnienia wewnętrznego rynku usług pocztowych, która będzie musiała zapewnić finansowanie wydajnej i wysokiej jakości usługi powszechnej, wzywa także Parlament Europejski, Radę i Komisję do niezwłocznej intensyfikacji dyskusji na ten temat i ich zakończenia z myślą o osiągnięciu porozumienia w sprawie dyrektywy w należytym czasie.

3. Rada Europejska wzywa Radę do szybkiego uzgodnienia pierwszych czterech wniosków w sprawie wspólnych inicjatyw technologicznych (ARTEMIS, inicjatywy dotyczącej wbudowanych systemów komputerowych; IMI, inicjatywy dotyczącej medycyny innowacyjnej; „czyste niebo”, inicjatywy dotyczącej aeronautyki i transportu lotniczego, a także ENIAC, inicjatywy dotyczącej technologii nanoelektronicznych); wzywa również Komisję, by jak najszybciej przedstawiła pozostałe wspólne inicjatywy technologiczne, o których mowa w szczegółowym programie „Współpraca” wykonującym 7. program ramowy w dziedzinie badań. Rada Europejska przypomina jak ważne jest otwarte i przejrzyste zarządzanie tymi inicjatywami.

4. Rada Europejska z zadowoleniem przyjmuje fakt, że trwają ożywione prace nad rozporządzeniem w sprawie Europejskiego Instytutu Technologii i w związku z tym wzywa Radę, by na posiedzeniu w dniu 25 czerwca uzgodniła podejście ogólne do tego rozporządzenia, w tym w kwestii stosownego finansowania zgodnie ze wspólnotowymi procedurami budżetowymi. Rada Europejska jest przekonana, że ostateczna decyzja Rady i Parlamentu Europejskiego zostanie podjęta przed końcem tego roku.

5. Rada Europejska potwierdza znaczenie Galileo jako kluczowego projektu Unii Europejskiej i wzywa Radę do podjęcia zintegrowanej decyzji w sprawie realizacji Galileo jesienią 2007 roku.

6. Rada Europejska z zadowoleniem przyjmuje inicjatywę w sprawie Karty Europejskiej dotyczącej korzystania $\mathrm{z}$ własności intelektualnej będącej w posiadaniu instytucji badawczych i uniwersytetów (IP-Charter), co ma poprawić transfer wiedzy pomiędzy środowiskami naukowymi a przemysłem, oraz jej wkład w rozwój europejskiej przestrzeni badawczej. Rada Europejska wzywa Komisję do przedstawienia na początku 2008 roku inicjatyw stanowiących kontynuację zielonej księgi w sprawie europejskiej przestrzeni badawczej.

7. W obszarze polityki społecznej należy zdecydowanie kontynuować prace nad koordynacją systemów zabezpieczenia społecznego z myślą o jak najszybszym rozwiązaniu pozostałych nierozstrzygniętych kwestii. Rada Europejska oczekuje zapowiedzianego komunikatu Komisji na temat elastyczności i pewności zatrudnienia (flexicurity), na podstawie którego przed końcem bieżącego roku możliwe będzie uzgodnienie wspólnych zasad; z zadowoleniem przyjmuje również postępy w opracowywaniu strategii czynnej integracji. Rada Europejska oczekuje przedstawienia zmienionego wniosku dotyczącego dyrektywy w sprawie minimalnych wymogów służących zwiększaniu mobilności pracowników dzięki łatwiejszemu gromadzeniu i zachowywaniu nieprzepadalnych uprawnień do dodatkowych emerytur, na podstawie którego prowadzone będą dalsze prace w tej dziedzinie. Wzywa się państwa członkowskie do szybkiej realizacji przyjętej niedawno wspólnotowej strategii na rzecz bezpieczeństwa i higieny pracy na lata 2007-2012, która wzmocni ogólne podejście do dobrego samopoczucia w pracy i przyczyni się do wznowienia działań profilaktycznych i usprawnień 
dla pracowników. Rada Europejska wzywa państwa członkowskie, Komisję i partnerów społecznych do intensywnego korzystania z Sojuszu dla Rodzin w celu promowania dobrych praktyk $i$ innowacyjnych metod podejścia do polityk przyjaznych rodzinie zgodnych z polityką publiczną poszczególnych państw członkowskich oraz w celu propagowania równości płci. Rada Europejska oczekuje na zapowiadane sprawozdanie Komisji podsumowujące sytuację społeczną.

8. Przedmiotem poważnego zaniepokojenia pozostaje HIV/AIDS. Działania służące zwalczaniu światowej pandemii HIV/AIDS powinny obejmować ogólne programy zapobiegawcze, szkolenie personelu opieki zdrowotnej, zwiększanie świadomości we wszystkich grupach społeczeństwa i zajęcie się kosztami leczenia. Rada Europejska wzywa Komisję do realizacji planu działania w sprawie zwalczania HIV/AIDS w Unii Europejskiej i krajach sąsiadujących w latach 2006-2009 oraz europejskiego programu przeciwdziałania HIV/AIDS, malarii i grú́licy przez działania zewnętrzne (2007-2011). Do państw członkowskich należy zapewnienie przywództwa politycznego w zwalczaniu tej pandemii. Przemysł farmaceutyczny powinien ułatwić dostęp do tanich leków i współpracować z instytucjami rządowymi i organizacjami pozarządowymi przy zapewnianiu kanałów dystrybucji lekarstw przeciw HIV/AIDS.

9. Rada Europejska przypomina swoje konkluzje z marca 2007 roku w sprawie zintegrowanej polityki dotyczącej klimatu i energii. Z zadowoleniem przyjmuje ważny sygnał wysłany ze szczytu G8, który odbył się w Heiligendamm. Wyraźne odniesienie do obniżenia emisji co najmniej o połowę do roku 2050, zaangażowania w proces UNFCCC (Ramowa konwencja Narodów Zjednoczonych w sprawie zmian klimatu) oraz osiagnięcia kompleksowego porozumienia dotyczącego okresu po roku 2012 przed 2009 rokiem stanowi obiecującą podstawę dla zbliżających się negocjacji w ramach UNFCCC, które powinny się rozpocząć na Bali w grudniu 2007 roku. Rada Europejska zachęca wszystkie strony do aktywnego i konstruktywnego udziału w pilnej i globalnej reakcji na wyzwanie związane ze zmianami klimatu w oparciu o zasadę wspólnych, lecz zróżnicowanych obowiązków i odnośnych zdolności. Podkreśla znaczenie skutecznej i sprawnej realizacji wszystkich aspektów wszechstronnego planu działania w dziedzinie energii z myślą o przyspieszeniu prac nad polityką energetyczną dla Europy. Odnośnie do ochrony klimatu Rada Europejska oczekuje terminowego przedstawienia przez Komisję wniosku dotyczącego zmiany dyrektywy w sprawie systemu UE handlu uprawnieniami do emisji (EU ETS) opartego na procesie przeglądu i zaleceniach Rady. Wzywa Komisję do rozważenia, w ramach przeglądu EU ETS, ewentualnego rozszerzenia zakresu systemu na użytkowanie gruntów, zmiany użytkowania gruntów i leśnictwo. Podkreśla zamiar Unii, by tym systemem zostały objęte działania w dziedzinie lotnictwa w taki sposób, by nie wpływało to negatywnie na konkurencyjność.

10. Coraz bardziej oczywistym staje się fakt, że zmiany klimatu będą miały znaczny wpływ na zagadnienia bezpieczeństwa międzynarodowego. Rada Europejska wzywa Wysokiego Przedstawiciela i Komisję Europejską do ścisłej współpracy w tej istotnej kwestii oraz do przedstawienia wspólnego sprawozdania na posiedzenie Rady Europejskiej wiosną 2008 roku.

11. Rada Europejska przypomina, jakie znaczenie ma skuteczny i zrównoważony europejski system transportu i przyjmuje do wiadomości zamiar Komisji przedstawienia, 
nie później niż w czerwcu 2008 roku, modelu oceny wszystkich kosztów zewnętrznych, który posłuży jako podstawa przyszłych obliczeń opłat za korzystanie z infrastruktury. Modelowi temu będzie towarzyszyć ocena oddziaływania internalizacji kosztów zewnętrznych obejmująca wszystkie środki transportu oraz dalsze działania zgodne z dyrektywą o eurowinietach.

12. Rada Europejska z zadowoleniem przyjmuje ożywioną debatę, w szczególności w trakcie konferencji w Bremie w maju 2007 roku, która toczyła się w Europie na temat przyszłej polityki morskiej i wzywa Komisję do przedstawienia europejskiego planu działania przewidywanego na październik. Biorąc pod uwagę zasadę pomocniczości, wspomniany plan działania powinien mieć na celu zbadanie pełnego potencjału działalności gospodarczej związanej z morzem w sposób zrównoważony z punktu widzenia środowiska.

13. Rada Europejska gratuluje Cyprowi i Malcie stopnia konwergencji osiagniętego od momentu przystąpienia do UE, dzięki należytym politykom gospodarczym i finansowym, i z zadowoleniem przyjmuje fakt spełnienia przez oba kraje wszystkich kryteriów konwergencji określonych w Traktacie. W tym kontekście Rada Europejska z zadowoleniem przyjmuje wniosek Komisji dotyczący przyjęcia euro przez Cypr i Maltę 1 stycznia $2008 \mathrm{r}$.

\section{STOSUNKI ZEWNĘTRZNE}

\section{Europejska polityka sąsiedztwa}

VII. Rada Europejska potwierdza nadrzędne znaczenie europejskiej polityki sąsiedztwa (EPS), która ma na celu utrwalenie obszaru dobrobytu, stabilności i bezpieczeństwa w oparciu o prawa człowieka, demokrację i zasadę państwa prawnego, jak również wspieranie procesu reform i modernizacji w krajach partnerskich sąsiadujących z Unią.

VIII. Rada Europejska zatwierdza konkluzje Rady dotyczące wzmacniania europejskiej polityki sąsiedztwa oraz przygotowane przez prezydencje sprawozdanie z postępów obejmujące zestaw środków służących dalszemu wzmacnianiu polityki sąsiedztwa. Wprawdzie charakter EPS jako jednolitych i spójnych ram politycznych należy zachować, to jednak realizacja tej polityki powinna w należyty sposób uwzględniać specyficzną sytuację krajów partnerskich. Rada Europejska wzywa przyszłe prezydencje do dalszych prac na podstawie sprawozdania prezydencji oraz stosownych wniosków i komunikatów Komisji.

\section{Azja Środkowa}

IX. Rada Europejska przyjęła strategię UE dotyczącą nowego partnerstwa z Azją Środkową. Strategia ta posłuży jako ogólne ramy stosunków między UE a państwami Azji Środkowej, w tym w dziedzinach praw człowieka, państwa prawnego, dobrych rządów i demokracji, edukacji, rozwoju gospodarczego, handlu i inwestycji, energii i transportu, polityk dotyczących środowiska, oraz migracji i dialogu międzykulturowego. Strategia określa priorytety UE dotyczące wspólpracy 
z tym regionem jako całością, choć jej realizacja będzie dostosowana do konkretnych wymogów i wyników poszczególnych państw Azji Środkowej. Rada Europejska zwraca się do Rady i Komisji o regularny przegląd postępów w realizacji przedmiotowej strategii i przedłożenie pierwszego sprawozdania z postępów Radzie Europejskiej do połowy 2008 roku.

\section{Proces $\mathrm{z}$ Heiligendamm}

X. Rada Europejska, przypominając ewolucję instrumentów UE i forów dialogu z udziałem gospodarek wschodzących, z zadowoleniem przyjmuje zapoczątkowanie procesu z Heiligendamm przez szczyt G8 w czerwcu 2007 roku, który rozpoczyna nową formę dialogu w szczególności z Brazylią, Chinami, Indiami, Meksykiem i Republiką Południowej Afryki. Rada Europejska uznaje rosnące znaczenie, jakie maja powyższe i inne gospodarki wschodzące. Proces z Heiligendamm powinien przyczynić się do intensyfikacji dialogu politycznego i propagowania współpracy z przedmiotowymi krajami, szczególnie w dziedzinie innowacji i własności intelektualnej, warunków inwestycyjnych, w tym odpowiedzialnego prowadzenia działalności gospodarczej, efektywności energetycznej i współpracy na rzecz rozwoju.

\section{UE-Afryka}

XI. Drugi szczyt UE-Afryka w Lizbonie w grudniu 2007 roku będzie stanowił ważną okazję do wzmocnienia stosunków między UE a Afryką i stworzenia nowego, ambitnego i strategicznego partnerstwa.

XII. Przywołując swoje konkluzje z czerwca 2005 roku, Rada Europejska podkreśla znaczenie, jakie przywiązuje do dalszego zacieśniania współpracy z Unią Afrykańską w celu zadbania o to, aby wspólna strategia UE-Afryka mogła zostać przyjęta przed grudniem 2007 roku. Rada Europejska potwierdza zdecydowany zamiar dalszego popierania Unii Afrykańskiej z myślą, między innymi, o wzmocnieniu potencjału Unii Afrykańskiej w zakresie zarządzania konfliktami, ich rozwiązywania i zapobiegania im. Rada Europejska z zadowoleniem przyjmuje zamiar ustanowienia partnerstwa energetycznego UE-Afryka na szczycie $z$ udziałem obu stron.

XIII. Rada Europejska podkreśla potrzebę nowych uzgodnień umożliwiających szybkie uruchamianie środków finansowych UE w celu wsparcia szybkiego rozmieszczenia sił UA; kwestia ta powinna być traktowana priorytetowo. Rada potwierdza zobowiązania podjęte w ramach strategii UE zatytułowanej „UE i A fryka: w kierunku partnerstwa strategicznego" i zachęca państwa członkowskie do dołożenia wszelkich starań, aby osiagnąć określone w strategii cele.

\section{Europejska Polityka Bezpieczeństwa i Obrony}

XIV. Rada Europejska zatwierdza sprawozdanie prezydencji na temat EPBiO zawierające mandat dla kolejnej prezydencji. 


\section{IRLANDIA PÓLNOCNA}

XVI. Brytyjski premier i premier Irlandii Północnej przekazali Radzie Europejskiej informacje dotyczące przywrócenia obejmującego wszystkie strony, zdecentralizowanego i opartego na podziale władzy rządu w Irlandii Północnej. Rada Europejska $\mathrm{z}$ zadowoleniem przyjęła niedawne kontakty między przewodniczącym Komisji a nowym rządem Irlandii Północnej, podkreśliła także długotrwałe i stałe poparcie Unii Europejskiej dla procesu pokojowego.

\section{Dok. 3. Mandat Konferencji Międzyrządowej}

Niniejszy mandat będzie stanowić jedyną podstawę i ramy dla prac konferencji międzyrządowej, która zostanie zwołana zgodnie z pkt 10 konkluzji Rady Europejskiej.

\section{UWAGI OGÓLNE}

1. Konferencja międzyrządowa jest proszona o sporządzenie Traktatu (dalej zwanego „traktatem reformującym") zmieniającego obowiązujące Traktaty z myślą o zwiększeniu efektywności funkcjonowania rozszerzonej Unii i umocnieniu jej legitymacji demokratycznej, jak również spójności jej działań zewnętrznych. Zrezygnowano z koncepcji konstytucyjnej polegającej na uchyleniu wszystkich obowiązujących Traktatów i zastapieniu ich jednym tekstem zwanym „Konstytucja”. Traktat reformujacy wprowadzi do obowiązujących Traktatów, które pozostaja w mocy, przedstawione szczegółowo poniżej innowacje wynikające z ustaleń konferencji międzyrządowej w 2004 roku.

2. Traktat reformujacy będzie zawierał dwie zasadnicze klauzule zmieniające odpowiednio Traktat o Unii Europejskiej (TUE) oraz Traktat ustanawiajacy Wspólnotę Europejska (TWE). TUE zachowa swoją obecną nazwę, natomiast TWE będzie nosił tytuł Traktat o funkcjonowaniu Unii, a Unia nabędzie jednolitą osobowość prawną. Wyraz „Wspólnota" zostanie w całym tekście zastapiony wyrazem „Unia”; w tekście znajdzie się stwierdzenie, że te dwa Traktaty są Traktatami stanowiącymi podstawę Unii oraz że Unia zastępuje Wspólnotę i jest jej następcą prawnym. Dalsze klauzule będą zawierać standardowe postanowienia dotyczące ratyfikacji i wejścia w życie, a także ustaleń przejściowych. Zmiany techniczne Traktatu Euratom oraz obowiązujących Protokołów, ustalone podczas konferencji międzyrządowej w 2004 roku, zostaną wprowadzone przez protokoły załączone do traktatu reformujacego.

3. TUE i Traktat o funkcjonowaniu UE nie będą miały charakteru konstytucyjnego. Terminologia stosowana w całym tekście Traktatów będzie odzwierciedlać tę zmianę: nie będzie stosowany termin „Konstytucja”, ,minister spraw zagranicznych Unii” będzie nazwany Wysokim Przedstawicielem Unii ds. Zagranicznych i Polityki Bezpieczeństwa, odejdzie się także od stosowania określeń „ustawa” i „ustawa ramowa”, zostaną natomiast zachowane obecnie stosowane określenia „,rozporządzenia”, „dyrek- 